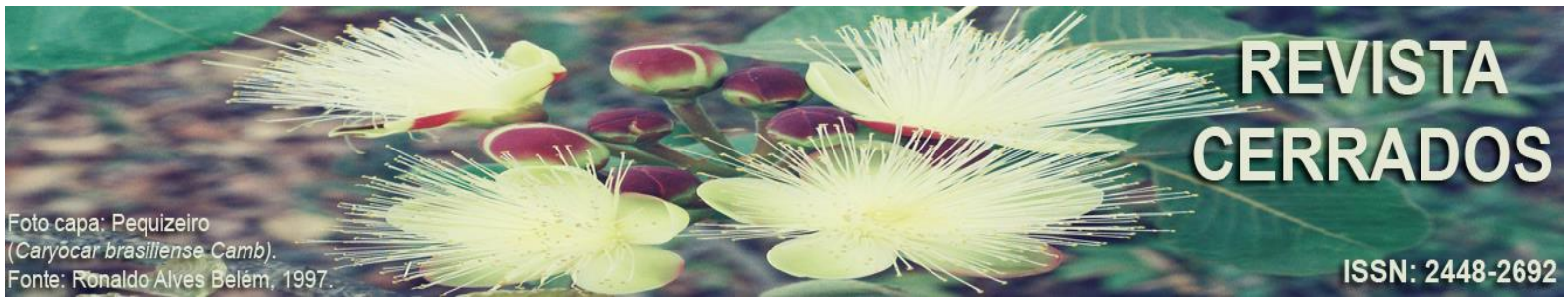

\title{
DA REVOLUÇÃO VERDE AO DISCURSO DO PRONAF: a representação do desenvolvimento nas políticas públicas de desenvolvimento rural no Brasil ${ }^{1}$
}

FROM GREEN REVOLUTION TO THE SPEECH OF PRONAF: the representation of development in public policies for rural development in Brazil

\section{DE LA REVOLUCIÓN VERDE AL DISCURSO DEL PRONAF: la representación de desarollo en las políticas públicas de desarrollo rural en Brasil}

\author{
Michell Leonard Duarte de Lima Tolentino \\ Instituto Federal do Tocantins - IFTO \\ E-mail: < michelltolentino@gmail.com>
}

\begin{abstract}
Resumo
Este trabalho procura refletir acerca das várias representações de desenvolvimento que embasam algumas das políticas públicas de desenvolvimento rural no Brasil, partindo das representações de desenvolvimento subjacentes à Revolução Verde e focando, posteriormente, no discurso do Programa Nacional de Fortalecimento da Agricultura Familiar (PRONAF). O trabalho se embasa em uma ampla pesquisa bibliográfica e documental. De início abordamos o discurso do desenvolvimento de forma crítica, para logo depois atentarmos para a maneira como este coloca o espaço rural. Para tanto utilizamos autores como Esteva (2000), Escobar (2000), Santos (1979) e Montenegro Gómez (2006). Posteriormente analisamos a Revolução Verde "brasileira" compreendendo o fordismo enquanto seu principal modelo de desenvolvimento. Em seguida, partimos para uma reflexão mais profunda sobre o PRONAF. O PRONAF assume fundamental importância nesse trabalho, pois o entendemos enquanto uma política de extrema relevância para se ler esse momento de inflexão das políticas públicas para o campo, de mudança nas representações sobre o espaço rural e o desenvolvimento rural brasileiro. Ao nos determos no PRONAF, discutimos a mudança de um modelo de desenvolvimento fordista para um modelo de desenvolvimento flexível.
\end{abstract}

\footnotetext{
${ }^{1}$ Uma versão anterior deste artigo foi publicada nos anais do XXI Encontro Nacional de Geografia Agrária, em Uberlândia, 2012.
} 
Palavras-Chave: Desenvolvimento; Políticas públicas; PRONAF; Revolução Verde.

\begin{abstract}
This article seeks to reflect on the various representations of development that underlie some of the public policies for rural development in Brazil, based on the development of representations underlying to Green Revolution and focusing later in the speech of the Programa Nacional de Fortalecimento da Agricultura Familiar (PRONAF). The study was grounded in an extensive bibliographic and documentary research. At first we approached the discourse of development in a critical way, for after we pay attention to the countryside's analysis. For this purpose we study authors as Esteva (2000), Escobar (2000), Santos (1979) and Montenegro Gómez (2006). Subsequently analyzed the Green Revolution "Brazilian" comprising Fordism as its main development model. Then, we set out to a deeper review on the PRONAF. The PRONAF is of fundamental importance in this article, as we understand it as an extremely important policy to read this turning point of public policy for the field of change in representations of the countryside and the Brazilian rural development. As we focused in PRONAF, we discussed the shift from a Fordist model of development for a flexible development model.
\end{abstract}

Keywords: Development; Public policies; PRONAF; Green Revolution.

\title{
Resumen
}

Este trabajo busca reflexionar acerca de las varias representaciones de desarrollo que son la base de algunas de las políticas públicas de desarrollo rural en Brasil, desde las representaciones de desarrollo subyacentes a la Revolución Verde, focalizando posteriormente en el discurso del Programa Nacional de Fortalecimiento de la Agricultura Familiar (PRONAF). Los resultados aquí presentados son el resultado de un análisis profundo de bibliografía y de documentos. En la primera parte de esta investigación abordamos el discurso del desarrollo de forma crítica para luego analizar de qué manera en este es colocado el espacio rural, apoyándonos en autores como Esteva (2000), Escobar (2000), Santos (1979) y Montenegro Gómez (2006). En una segunda parte, analizamos la Revolución Verde "brasileña" entendiendo el fordismo como su principal modelo de desarrollo, y una tercera parte, hacemos una reflexión más profunda sobre el PRONAF, siendo este un programa que toma fundamental importancia en nuestra investigación, ya que es una política de extrema relevancia para hacer una lectura del momento de inflexión entre las políticas públicas para el campo, de cambio en las representaciones sobre el espacio rural y el desarrollo rural brasilero. Al centrar nuestro interés en el PRONAF, estamos discutiendo el cambio de modelo de desarrollo fordista para un modelo de desarrollo flexible.

Palabras Clave: Desarrollo; Políticas públicas; PRONAF; Revolución Verde. 


\section{INTRODUÇÃO}

Neste artigo temos por objetivo refletir sobre as várias representações de desenvolvimento que perpassaram algumas das políticas públicas de desenvolvimento rural implementadas no Brasil, partindo da Revolução Verde e atendo-se, posteriormente, de maneira pormenorizada ao Programa Nacional de Fortalecimento da Agricultura Familiar (PRONAF).

"Mas o que é desenvolvimento?"

Remetamo-nos ao fim da Segunda Guerra Mundial e à posição de destaque alcançada pelos Estados Unidos ao final da mesma. Os Estados Unidos estavam indiscutivelmente ao centro do mundo, eram seu "senhor". "Todas as instituições criadas naqueles anos reconheciam esse fato; a própria Carta das Nações Unidas era uma cópia da Constituição norte-americana." (ESTEVA, 2000, p. 59).

Entretanto, como bem coloca Esteva (2000), estar ao centro do mundo não era o bastante. Era necessário consolidar sua hegemonia, daí lança-se toda uma campanha com a marca dos Estados Unidos e um dos momentos emblemáticos ocorre quando em 20 de janeiro de 1949, Truman, presidente dos Estados Unidos, discursa:

É preciso que nos dediquemos a um programa ousado e moderno que torne nossos avanços científicos e nosso progresso industrial disponíveis para o crescimento e para o progresso das áreas subdesenvolvidas.

O antigo imperialismo - a exploração para lucro estrangeiro - não tem lugar em nossos planos. O que imaginamos é um programa de desenvolvimento baseado nos conceitos de uma distribuição justa e democrática. (TRUMAN apud ESTEVA, 2000, p. 59-60) (grifos nossos).

Assim, os Estados Unidos lideravam a corrida para prover os países "subdesenvolvidos" de desenvolvimento. As representações que colocavam os países explorados como bárbaros e os países exploradores como civilizados foram substituídas, agora a representação corrente era que tínhamos subdesenvolvidos em relação aos desenvolvidos. Tudo ocorre como se os "pobres países pobres" necessitassem da ajuda do grande "amigo" do norte.

$\mathrm{Na}$ esteira dos acontecimentos, produziu-se a representação do Terceiro Mundo e os países que a eles pertenciam eram todos subdesenvolvidos. Assim discutiu-se o desenvolvimento destas áreas e a pobreza, um fenômeno qualitativo foi quantificado. Como 
sempre, os números são considerados provas cabais, necessárias à "cientificidade" e mais necessárias ainda às intervenções, à dominação.

As técnicas e práticas do planejamento foram essenciais para o desenvolvimento desde seu início. Simbolizando a aplicação do conhecimento científico e técnico ao setor público, o planejamento deu legitimidade à tarefa do desenvolvimento $e$ alimentou as esperanças nele depositadas. De um modo geral, o conceito de planejamento implica a certeza de que mudanças sociais podem ser forjadas e dirigidas, ou até produzidas quando desejadas (ESCOBAR, 2000, p. 211).

Daí se depreendeu a necessidade de se adquirir tudo do exterior, sendo necessário que os países centrais “ajudassem” os países pobres.

Era preciso demonstrar que os países subdesenvolvidos eram incapazes de acumular internamente o capital para seus investimentos modernizantes e, portanto, provar a necessidade de lhes fornecer ajuda ou de lhes emprestar dinheiro, ou ainda de encorajar a entrada de capital privado (SANTOS, 1979, p 8).

Havia, assim, um discurso, um conjunto organizado de representações, que justificava os endividamentos massivos por parte de todo o Terceiro Mundo, tendo os países do Primeiro Mundo, principalmente os Estados Unidos, como seus credores, ou melhor, dominadores.

O desenvolvimento, assim, sempre prescreveu um caminho que tinha como "modelo perfeito" os países centrais, de maneira que toda trajetória de desenvolvimento consiste numa tentativa de percorrer o mesmo caminho dos países do chamado "mundo desenvolvido".

No interior dessa abordagem crítica ao desenvolvimento, Montenegro Gómez (2006) coloca que o espaço rural brasileiro é duplamente candidato ao desenvolvimento. Em primeiro lugar porque o Brasil é um país considerado subdesenvolvido, em segundo lugar porque o rural simplesmente é rural, "parente pobre e atrasado" do espaço urbano.

O discurso do desenvolvimento coloca o espaço rural como sinônimo de atraso, de ignorância e de pobreza, enfim de subdesenvolvimento. Este rural teria, pois, que ser transformado. Mas qual seria a receita para desenvolver o rural? Que remédios seriam estes que "curariam" o rural?

Bem, as prescrições destas receitas só poderiam ser dadas por especialistas vindos dos países desenvolvidos, já que estes, segundo o discurso do desenvolvimento, estão bem. 
As receitas, assim, sempre foram prescritas a partir do modelo de desenvolvimento que se coloca enquanto hegemônico e hegemonia quer dizer domínio.

Desse modo, interessa a este trabalho analisar as diversas representações acerca do desenvolvimento rural que atravessaram algumas das principais políticas públicas brasileiras, partindo da Revolução Verde e se detendo mais atentamente ao PRONAF.

$\mathrm{O}$ artigo, além da introdução e das considerações finais, é estruturado em três tópicos. No primeiro tópico abordamos o primeiro grande formato de políticas de desenvolvimento rural que atingiu o espaço rural brasileiro, a Revolução Verde. Veremos que muito do PRONAF se deve às frustrações decorrentes do modelo de "Revolução Verde". Já no segundo tópico refletiremos sobre o modelo de desenvolvimento no qual o PRONAF se assenta quando do seu surgimento. No terceiro tópico, veremos as várias críticas sobre o modelo de desenvolvimento rural do PRONAF e por fim nos deteremos nas diversas modificações do PRONAF, decorrentes, em grande parte, das críticas voltadas ao programa.

\section{Da Revolução Verde "brasileira" ao discurso do PRONAF}

Inserido em um modelo de desenvolvimento fordista, as representações hegemônicas, difundidas durante a Revolução Verde, preconizavam a tão sonhada modernização a partir da industrialização da agricultura.

Partindo da quimificação e da mecanização como basilares para a modernização, o setor industrial (não era a indústria o lócus primordial do fordismo?) passava a subordinar a agricultura. Essa submissão se dava a montante e a jusante do processo produtivo. A montante porque a agricultura teria de adquirir maquinário, implementos e insumos químicos das indústrias, criando assim um grande mercado para a aquisição de produtos industriais, a jusante porque deveria fornecer matérias-primas para a agroindústria, tanto no mercado interno quanto externo. É justamente neste momento que se instalam no Brasil uma série de indústrias sediadas no "Primeiro Mundo" e produtoras de bens de produção para a agropecuária como Ford, Shell, Ciba Geyge, ICI, UNILEVER, Du Pont, Bayer, Basf, Stauffer, Dow Química, Pfizer, Union Carbide, Hoeschte, Monsanto, Rhodia, etc. Erigia-se assim o que ficou conhecido como Complexo Agroindustrial (CAI) brasileiro.

É consenso na literatura sobre as transformações no setor agrícola brasileiro "que o processo de tecnificação da base produtiva teve início na década de cinquenta e ocorreu com 
a importação dos meios de produção (sobretudo máquinas agrícolas)" (MARAFON, 1998, p.7). Contudo, somente a partir do final da década de 1960, é que:

foi implantado no Brasil um setor industrial produtor de bens de produção voltado para a agricultura. Paralelamente à implantação desse setor ocorreu a modernização e o desenvolvimento, em escala nacional, de um mercado para os produtos industriais do sistema agroindustrial. Esse processo ficou conhecido como "modernização da agricultura" e nele ocorreram modificações significativas na forma de se produzir (MARAFON, 1998, p. 7).

Para que o CAI se fizesse, toda uma estrutura foi criada pelo governo federal. Primeiramente criou-se o Serviço Nacional de Crédito Rural (SNCR) para que fosse fornecido o crédito necessário aos grandes proprietários, principalmente. " $\mathrm{O}$ crédito agrícola se transformou, sem dúvida, no maior impulsionador do processo de modernização das forças produtivas, em particular, da mecanização, chegando por vezes a subsidiar praticamente mais da metade do valor da maquinaria agrícola" (SORJ, 1980, p. 48).

O surgimento do CAI brasileiro pode ser visto enquanto a reafirmação de um discurso que se dava a partir de representações que defendiam a necessidade imperativa da industrialização da agricultura. Esta por sua vez se traduzia na subordinação de um espaço rural, identificado nas representações amplamente com a agropecuária, a um espaço urbano, por sua vez identificado com a indústria.

Outro fator que também reforça na prática o caráter urbano e industrial difundido pela estratégia da Revolução Verde é o fato de o governo brasileiro ter priorizado o apoio à modernização das grandes propriedades. Recordemos, no entanto, que apesar de a Revolução Verde fordista no Brasil ter privilegiado a grande propriedade, isso não é uma regra para o mundo todo. Na França, por exemplo, o fordismo modernizou a agricultura camponesa francesa, base da economia agrícola naquele país. No Brasil, embora a maior parte da população rural fosse formada por camponeses, a escolha foi majoritariamente pela grande propriedade.

"Mas por que isso?"

$\mathrm{Na}$ verdade, como nos diz Oliveira (1999) “a industrialização da agricultura brasileira vem sendo feita no interior do processo de internacionalização da economia brasileira" (p. 76). A partir desse processo de internacionalização engendrou-se todo um mecanismo de dependência que, ao invés de desenvolver o país, como era propalado, nos tornou ainda mais subordinados aos países centrais. 
(...) diferentes governos brasileiros têm tomado dinheiro emprestado no mercado financeiro internacional, com a finalidade de ampliar a sua produção, particularmente no setor industrial. Para pagar a dívida o país tem que exportar, isto é, tem que se sujeitar a vender seus produtos pelos preços internacionais.

É por isso que, nas últimas décadas, tem ocorrido no Brasil uma rápida expansão das culturas de produtos agrícolas para a exportação (café, cana-de-açúcar, soja, laranja etc.), quase sempre em detrimento daqueles produtos alimentícios destinados ao mercado interno (arroz, feijão, mandioca etc.), produtos esses que deveriam servir ao consumo da população brasileira. (OLIVEIRA, 1999, p.77) (grifos nossos).

Ocorre que a maioria dos habitantes do campo, tanto nesse período quanto atualmente, não é formada por grandes proprietários, mas sim por camponeses que não possuem nem sequer médias propriedades.

Com a mecanização empreendida pela Revolução Verde nas grandes propriedades, antigas relações de trabalho que se davam entre o grande proprietário e o camponês começaram a ocorrer em condições cada vez mais difíceis para este último. Se antes o camponês era uma força de trabalho da qual o latifundiário não podia prescindir, agora o camponês não é tão imprescindível assim.

Dessa maneira, ao mesmo tempo em que as possibilidades de reprodução camponesa foram se tornando cada vez mais estreitas no campo, o emprego na indústria aumentava fortemente na cidade. A migração para a cidade com o intuito de trabalhar na indústria tornou-se cada vez mais um caminho a ser seguido pelos camponeses. Data desse período uma importante transformação na distribuição geográfica da população brasileira. Se antes, o Brasil era um país onde a maior parte da população morava no campo, agora a população brasileira passa a viver predominantemente nas cidades.

Dessa forma, o modelo de desenvolvimento é reafirmado na prática. Ele deixa de ser somente um discurso com representações organizadas. Os camponeses, considerados ineficientes pelas representações veiculadas no período em que imperou o modelo de desenvolvimento fordista, foram realmente levados, em sua grande parte, a migrarem para as cidades e lá se tornaram operários das fábricas. Nesse contexto, também houve muitos que se tornaram operários das indústrias do campo ou foram levados para as áreas de colonização na Amazônia, continuando a se reproduzir como camponeses, tais como muitos que permaneceram nos seus lugares de origem. No entanto, tudo nos leva a crer que a Revolução Verde em seu discurso e em sua prática advogava muito mais uma territorialização do capital 
do que uma monopolização do território pelo capital, embora essa última também se ocorresse contraditoriamente na prática. (cf. OLIVEIRA, 1999).

Como expõe Oliveira (1999):

É verdade que existe uma forte articulação entre a indústria e a agricultura, como é verdade também que ocorre a expansão do trabalho assalariado no campo, mas não é verdade que o domínio absoluto do modo industrial de produzir se verifique juntamente com a expansão total do trabalho assalariado no campo. É fundamental explicar que o capital não transforma de uma só vez todas as formas de produção em produção ditadas pelo lucro capitalista. O desenvolvimento do capitalismo se faz de forma desigual e contraditória (p. 77).

Entretanto, por mais contraditório que fosse o processo, aqueles que davam sustentação às representações de desenvolvimento fordista ocultavam suas contradições. Deste modo advogou-se que, país com agricultura moderna e desenvolvida era país com uma agricultura assentada em um modo industrial de produzir. E são "típicos" deste momento a expansão do trabalho assalariado, o aumento da população urbana em detrimento da população rural e o crescimento da indústria subordinando a agropecuária. Contudo, ao ocultarem as contradições do processo, as representações hegemônicas mobilizadas durante o modelo de desenvolvimento fordista ocultavam, até certo ponto, os limites desse modelo de desenvolvimento. Foram as contradições desse modelo que levaram ao esgotamento do mesmo enquanto modelo hegemônico.

Ocultando as contradições subjacentes a qualquer processo social, o discurso que justificava a prática da Revolução Verde tentava prescrever o destino dos camponeses. Seu destino já estaria traçado, planejado, a eles não caberia alternativa.

Entretanto não tardou muito para que se criassem políticas públicas que tentavam incorporar os camponeses ao desenvolvimento pela via fordista. Nessa esteira, ainda nos anos 1970, foram criados os Projetos de Desenvolvimento Rural Integrado (PDRI). Constituem-se em exemplos deste período políticas como o Programa de Desenvolvimento de Áreas Integradas do Nordeste (POLONORDESTE), Programa de Desenvolvimento da Região Centro-Oeste (POLOCENTRO) e Programa de Polos Agropecuários e Agrominerais da Amazônia (POLAMAZONIA).

Estes programas surgem a partir do paradigma do desenvolvimento regional, tendo como seus gestores órgãos como a Superintendência de Desenvolvimento do Nordeste (SUDENE), Superintendência de Desenvolvimento da Amazônia (SUDAM) e 
Superintendência de Desenvolvimento do Centro-Oeste (SUDECO). No mesmo período também foram levadas a cabo outras ações de caráter desenvolvimentista. Abordando o caso específico do Nordeste, Elias (2000) coloca:

Em meados do século XX, o Brasil atravessava um momento de efervescência com as teorias desenvolvimentistas, com amplos debates sobre as desigualdades regionais brasileiras. Criaram-se neste período, inúmeras instituições visando a intervenção federal no Nordeste, tais como a SUDENE (Superintendência de Desenvolvimento do Nordeste), do BNB (Banco do Nordeste), da CODEVASF (Companhia do Desenvolvimento do Vale do São Francisco), assim como a construção de grandes fixos associados à infra-estruturas produtivas (ELIAS, 2000, p. 87).

Estes órgãos, que também viabilizaram grande parte da Revolução Verde, foram criados com o intuito de incentivar a industrialização, a construção de obras de infraestrutura e a modernização do setor agropecuário brasileiro. Enfim, foram órgãos criados para levar a cabo o modelo de desenvolvimento fordista.

Políticas como o POLONORDESTE, POLOCENTRO e POLAMAZÔNIA só vinham reafirmar ainda mais o modelo hegemônico. O POLONORDESTE, por exemplo, tinha entre as, de acordo com Albano (2005) a reorganização agrária e a complementação da infraestrutura, pesquisa, assistência técnica, crédito e comercialização. Em cada polo, ter-seiam ações para a construção de estradas, armazéns, obras de eletrificação, além do crédito, da extensão da pesquisa e da experimentação agrícola. Os polos seriam "pontos naturais" de recepção de investimentos que, uma vez potencializados, poderiam irradiar os efeitos dinamizadores, havendo o estímulo à modernização industrial do Nordeste. Havia, portanto, um claro favorecimento de um modelo economicista e de racionalidade empresarial. Sobre o POLONORDESTE, Andrade (1986) afirma que o mesmo é um "programa que teoricamente visa ao fortalecimento e à modernização da pequena e média exploração agrícola” (p. 196). "O POLONORDESTE é o marco da intervenção do Banco Mundial na agropecuária nordestina" (ELIAS, 2000, p. 89)².

\footnotetext{
${ }^{2}$ Apesar de fordista, devemos sempre lembrar que o POLONORDESTE, por exemplo, já era um contraponto à chamada "via prussiana", a escolha da modernização das grandes propriedades. Antes do POLONORDESTE foi tentado, entretanto, o Programa de Redistribuição de Terras e Estímulos à Agroindústria do Norte e Nordeste (PROTERRA) com o objetivo de realizar, na Zona da Mata, a redistribuição parcial de terras, de maneira pacífica, criando assim unidades de produção modernizadas de tamanho médio, com produção voltada para o mercado interno.

Portanto, paralelamente ao modelo "prussiano" de "modernização conservadora", há uma preocupação constante com a necessidade de se criar uma "classe média rural", de produtores capitalistas de tamanho médio. "Este objetivo deveria ser alcançado, principalmente, através da eliminação do setor minifundiário, se bem que
} 
Apesar de suas inúmeras ações, o fordismo já vinha dando sinais de esgotamento há algum tempo em todo o mundo. No Brasil, o aprofundamento da crise fiscal do Estado brasileiro, entre o fim da década de 1970 e início da década de 1980, fez com que ocorresse o fim do padrão de financiamento da modernização da agricultura consubstanciado no crédito rural oficial a baixas taxas de juros.

\begin{abstract}
Os programas recessivos de ajuste de impostos pelo Fundo Monetário Internacional, a pretexto de combater o déficit público, impediram que o Tesouro Nacional, via Banco do Brasil, pudesse continuar bancando os volumes demandados de crédito rural nos anos 80. A saída foi reduzir os níveis de subsídios embutidos, basicamente trocando as taxas nominais prefixadas (numa conjuntura de ascensão inflacionária) por pós-fixadas (GRAZIANO DA SILVA, 1996, p. 51).
\end{abstract}

As lutas dos camponeses contra a expropriação que o modelo de desenvolvimento lhes impunha se aprofundavam. O colapso do fordismo trazia as reivindicações ainda mais à tona, uma vez que todos os problemas desse modelo de desenvolvimento apareciam de maneira clara. Surgem movimentos importantes no campo, como o MST (Movimento dos Trabalhadores Rurais Sem-Terra), e a CPT (Comissão Pastoral da Terra) ganha força.

Com o passar dos anos, o MST, nascido em meados da década de 1980, se espalhou por todo o Brasil e na década de 1990 deu demonstrações cada vez maiores de força. Além do MST, outros movimentos surgiram. As ocupações de terras se avolumaram, os conflitos agrários estiveram na ordem do dia, a violência com que foram reprimidos os camponeses em Eldorado dos Carajás e Corumbiara "chocou" o mundo, o latifúndio foi amplamente contestado pelos movimentos sociais, a questão agrária se impôs ao governo brasileiro. Não havia como negar que as desigualdades que marcavam o campo brasileiro haviam se tornado insustentáveis. Nesse contexto de acirramento das lutas que envolviam a questão agrária, o governo federal cria o Ministério Extraordinário de Política Fundiária (MEPF).

Entretanto, o capital, em nível macroeconômico, com seus organismos internacionais, respondia aos camponeses com políticas de desenvolvimento que em nada

ocasionalmente se conceba sua implementação às expensas das propriedades improdutivas" (WILKINSON, 2008, p. 11-12).

O Proterra, na medida em que confontava os grandes proprietários de terra, acabou por fracassar. Por isso, segundo Wilkinson (2008), criou-se o POLONORDESTE: "o POLONORDESTE tem uma preferência marcada pelo incremento da produtividade, ao invés da Reforma Agrária” (WILKINSON, 2008, p. 17). 
transformavam suas contradições. O Banco Mundial (BM) já produzia estudos acerca da agricultura brasileira, nos quais delineava as bases teóricas (representações!) pelas quais as políticas de desenvolvimento deveriam ser criadas. Um símbolo desse momento é o relatório "Brasil. O Gerenciamento da Agricultura, do desenvolvimento rural e dos recursos naturais".

Nesse ínterim, a CONTAG e o DNTR-CUT, percebendo a relevância do debate da questão camponesa, fizeram reivindicações em busca de uma política que atendesse aos camponeses. As reivindicações se faziam de maneira insistente durante o Grito da Terra Brasil. Nesse sentido, é bastante relevante reafirmar que o PRONAF, mesmo sendo uma política de desenvolvimento com premissas do $\mathrm{BM}$, foi criado também a partir das reivindicações de alguns movimentos sociais, trazendo em seu cerne essa contradição.

$\mathrm{Na}$ verdade, tais reivindicações se faziam desde o ano de 1992. Entre 1992 e 1996, de acordo com Bittencourt (2003), apesar da pauta de negociações incluir temas relacionados à infraestrutura, meio-ambiente e tecnologia, o que se colocava no centro das questões, por parte dos camponeses, era sempre o acesso a um crédito diferenciado. Isso acabou levando o Governo Federal a colocar em prática o Programa de Valorização da Pequena Produção Rural (PROVAP), ainda no ano de 1994. O PROVAP foi uma linha de crédito que adotou critérios que restringiam os empréstimos apenas aos agricultores familiares, classificados assim de acordo com o tamanho das suas propriedades e o tipo de mão de obra que utilizavam.

Em 1995, já no governo FHC, foi criado o Plano Nacional de Fortalecimento da Agricultura Familiar (PLANAF), que logo produziu o PRONAF. A institucionalização do PRONAF, só ocorreu em 1996, através da lei nº 1946 de 28 de junho de 1996.

\section{Representações fordistas, pós-fordistas ou flexíveis no PRONAF?}

Os modelos de desenvolvimento não devem ser entendidos como estruturas estáticas, que barram o movimento, como fechamentos. Como Lipietz (1988) bem argumenta: "esses nomes são apenas conceitos com os quais procuramos descobrir alguns aspectos da realidade, da mesma maneira como se usam tochas para descobrir uma caverna" (p. 12). A partir deste conceito estamos tentando compreender quais processos que estão na origem do 
discurso do PRONAF, que representações são veiculadas, sem, contudo, subsumir o próprio processo de construção da política pública ao modelo de desenvolvimento.

É a partir dessa interpretação que queremos entender melhor as representações que são veiculadas pelo discurso do PRONAF em seu movimento, não tentando fechá-lo em um modelo acabado de desenvolvimento.

Entendido isso, analisemos o discurso do PRONAF desde o começo desse programa, quando ainda guardava inúmeras representações fordistas, apesar de ter sido elaborado em um período em que o modelo de desenvolvimento fordista já era algo plenamente contestável, sobretudo nos países centrais. Como veremos, em seu início, suas representações pouco tinham a ver com o modelo de desenvolvimento flexível.

A compreensão que perpassava o programa prezava por representações de espaço rural e de camponês diferentes daquelas que eram disseminadas sob o parâmetro da acumulação flexível. Era muito mais próximo de um "fordismo rural" do que de uma política para um espaço rural revalorizado, algo bastante presente nas representações do espaço rural difundidas pela acumulação flexível. O produtivismo agrícola, característico do fordismo, comparecia demasiadas vezes no texto que fundamentava o PRONAF. Trechos como os citados no $2^{\circ}$ parágrafo da lei evidenciam isso

$\S 2^{\circ}$ As ações do Programa orientar-se-ão pelas seguintes diretrizes:

a) melhorar a qualidade de vida no segmento da agricultura familiar, mediante promoção do desenvolvimento rural de forma sustentada, aumento de sua capacidade produtiva e abertura de novas oportunidades de emprego e renda,

b) proporcionar o aprimoramento das tecnologias empregadas, mediante estímulos à pesquisa, desenvolvimento e difusão de técnicas adequadas à agricultura familiar, com vistas ao aumento da produtividade do trabalho agrícola, conjugado com a proteção do meio ambiente;

(...)

d) adequar e implantar a infra-estrutura física e social necessária ao melhor desempenho produtivo dos agricultores familiares (PRONAF, 1996) (grifos nossos).

Analisando tais diretrizes, Carneiro (1997) destaca:

As diretrizes do Pronaf têm como referência experiências européias, principalmente a da França, que elegeram a agricultura familiar como a forma de produção sobre a qual se implementou, no pós-guerra, a modernização da produção agrícola e da sociedade rural.

Assim como na Europa, o padrão de organização da produção privilegiado pelo Pronaf e a sua função social no desenvolvimento econômico do país estão sustentados, implicitamente, nas noções de produtividade e na rentabilidade crescentes, o que resultaria, segundo os formuladores desse programa, em uma contribuição do setor para a competitividade da economia nacional e, em 
conseqüência, na melhoria da qualidade de vida da população rural (CARNEIRO, 1997).

Dessa forma, se inscreve no PRONAF um discurso fordista que se voltava para os pequenos. O modelo de desenvolvimento fordista, no entanto, apoia um protagonismo da cidade sobre o campo e o leitor poderia se perguntar se não seria um contrassenso chamarmos de fordista uma política de desenvolvimento que colocava camponeses como o seu alvo. Esclarecemos que o modelo fordista francês realmente propunha a mecanização da produção camponesa porque eles são a base da agricultura francesa. Todavia, esse mesmo modelo fordista francês adotava o padrão de 2 UTH (unidades de trabalho-homem), isto é, a força de trabalho empregada no estabelecimento resumia-se à do casal. Aos filhos dos camponeses era dirigido um programa educacional que os orientava para setores não-agrícolas. Assim, defendia-se uma agricultura moderna e produtivista, que empregava pouca mão de obra. No entanto, essa agricultura moderna era extremamente dependente de pacotes tecnológicos só adquiridos a partir da indústria. O espaço rural era, pois, identificado pelo fordismo a partir do produtivismo agrícola, sendo posto como secundário, a cidade é que era central, o nãoagrícola, que em uma sociedade industrial só podia fazer referência ao setor fabril. Assim, Carneiro (1997) comenta os resultados decorrentes do fordismo francês no campo.

\footnotetext{
Os resultados econômicos, rapidamente alcançados, melhores que os esperados, ocasionaram, porém, um novo problema social e ambiental: a desertificação do campo e o inchamento de algumas cidades, incapazes de absorver a mão-de-obra dispensada pelo novo padrão de produção agrícola. (CARNEIRO, 1997, p 04) (grifos nossos).
}

Todos esses problemas, ocorridos na França, vieram à baila com a crise fordista e com a posição de centralidade que o espaço urbano tinha sobre o espaço rural. Além disso, diferente do Brasil, todas as mudanças ocorridas no campesinato francês contaram com grandes investimentos por parte do Estado-providência, necessários à regulação fordista. No Brasil, como o Governo FHC possuía muito mais uma orientação neoliberal, não se utilizou de maiores aportes financeiros que procurassem dar uma maior assistência ao campesinato.

Além disso, se por um lado o PRONAF guardava elementos predominantemente fordistas, por outro, a descentralização do desenvolvimento local implementada pelo PRONAF Infraestrutura e Serviços Municipais já comparecia em seu primeiro formato, quando propõe: 
Art. $3^{\circ}$ Caberá ao Ministério da Agricultura e do Abastecimento a coordenação do PRONAF, competindo-lhe, especialmente:

(...)

VI - assegurar o caráter descentralizado de execução do PRONAF e o estabelecimento de processos participativos dos agricultores familiares e de suas organizações na implementação e avaliação do Programa. (PRONAF, 1996).

Para que a gestão descentralizada ocorresse, deveriam ser montados conselhos nas escalas nacional, estadual e municipal. No caso dos Conselhos Municipais de Desenvolvimento Rural $\left(\mathrm{CMDR}^{3}\right)$, os chamados "agricultores familiares", para nós camponeses, teriam algumas incumbências, como: a) apresentar e priorizar suas demandas; b) participar da execução do PRONAF e c) aportar as contrapartidas de sua competência. Às organizações de agricultores familiares cabia: a) formular propostas de ação compatibilizadas com as demandas dos agricultores; b) participar da elaboração e da execução do PMDR (Projeto Municipal de Desenvolvimento Rural e do acompanhamento e fiscalização das ações do PRONAF; c) celebrar e executar acordos, convênios e contratos com órgãos de administração pública e entidades parceiras privadas e d) aportar as contrapartidas de sua competência.

Havia, portanto, diretrizes que tiravam de cena o Estado centralizador, principal planejador e executor de políticas públicas, que sempre se impunham de cima para baixo. Prevalecia uma representação que prezava por um desenvolvimento autocentrado, endógeno, que se faz de baixo para cima. Esta ideia, que está presente no que estamos chamando de discurso do PRONAF, reconhece de algum modo as impossibilidades do capitalismo de fazer tudo se tornar seu mero reflexo e passa a entender que as resistências ao modo de produção podem ser modificadas, de maneira que sejam moldadas aos interesses do capital. A "animalidade" dos lugares não deve mais ser combatida de todo, mas antes transformada. Ocultam-se, mais uma vez as contradições subjacentes ao próprio modo de produção, que por sua vez se funda justamente no contraditório.

Essa representação de descentralização se coaduna com representações mobilizadas pelo discurso do Banco Mundial, quando este órgão afirma: "Há uma necessidade de se envolver, também, as comunidades locais no desenho e na implementação

\footnotetext{
${ }^{3}$ Posteriormente os CMDR passaram a ser chamados de CMDRS, Conselhos Municipais de Desenvolvimento Rural Sustentável.
} 
dos gastos públicos nas áreas rurais” (BANCO MUNDIAL apud VILELA, 1997, p. 5). Entretanto, também é importante nuançarmos um pouco isso, colocando que essa representação, ao reconhecer fatores endógenos enquanto vetores de mudanças, também responde a um anseio de representação de diversos atores.

Existia, no entanto, um PRONAF que ao se constituir enquanto política, utilizavase de diversas representações, produzindo um discurso que unia representações difundidas no contexto de diferentes modelos de desenvolvimento, mas que de fato possuía um conteúdo muito mais fordista. Prova disso é a estrita identificação que se fazia do programa com a busca do produtivismo agrícola, de maneira que o espaço rural era concebido como sinônimo de setor agrícola, representação cara ao desenvolvimento fordista.

$\mathrm{Na}$ nossa compreensão, muitas dessas representações que acabavam se contradizendo no interior da proposta do PRONAF, podem ser explicadas pelo contexto em que ela é forjada. Ao mesmo tempo em que o programa surge das contestações e dos fracassos decorrentes da Revolução Verde, o mesmo se vale de premissas europeias, sobretudo francesas, para introduzir o campesinato na via fordista, uma via que já havia apresentado problemas na própria agricultura francesa.

“E por que incorrer no erro?" Simplesmente, porque enquanto no caso francês o campesinato havia sido incluído na via fordista, uma vez que estes sempre foram a base de sua agricultura, no Brasil, isso não ocorreu. É como se a solução fordista francesa fosse aqui tomada tentando "corrigir" a opção pela chamada "via prussiana" que a industrialização da agricultura brasileira havia tomado. Os camponeses, que na década de 1990 já estavam lutando mais uma vez por Reforma Agrária, estavam se tornando problemáticos demais para o Estado brasileiro. Daí surgem políticas de desenvolvimento, marcadamente fordistas, para eles. Entretanto, a essa altura a totalidade do modelo fordista de desenvolvimento não era mais aceito e outras representações circulavam com força, seja na academia, nas instituições governamentais ou até mesmo no discurso cotidiano. A "solução francesa" agora tinha que abrir concessões a essas outras representações.

Apesar disso, nunca é demais lembrar que se o PRONAF parecia obsoleto frente às novas representações de desenvolvimento, o mesmo estava de acordo com as premissas do Banco Mundial. 
As "incoerências" do PRONAF, no que diz respeito às representações que o sustentam, não demorariam a ser criticadas por vários estudiosos. Elas demarcam o ponto de partida do PRONAF, caracterizado por uma verdadeira luta simbólica pelo poder de definir o que é o espaço rural brasileiro. Vejamos a seguir os desdobramentos dessa luta.

\section{Mudanças no discurso do PRONAF: mobilizando outras representações}

Nessa luta simbólica pelo poder de definir qual o discurso oficial, aquele que por ser considerado "verdade objetiva" não é vista como representação, teóricos se confrontam. Nesse sentido, Graziano da Silva e Grossi (2000), sem citarem explicitamente o PRONAF, fizeram críticas ao modo como estavam sendo elaboradas as políticas de desenvolvimento rural até então. Sobre isso afirmam:

O grande problema é que ainda hoje as políticas agrícolas ${ }^{4}$ e agrárias são desenhadas para agricultores "full time", ou seja, para as famílias que dedicam todo o seu tempo às atividades agrícolas internas ao seu estabelecimento. $\mathrm{O}$ não alargamento das diretrizes de políticas públicas impede o acesso dos pluriativos às políticas para o setor, e consequentemente contribui com a omissão do poder público para com esse segmento crescente de agricultores. (GRAZIANO DA SILVA e GROSSI, 2000 p. 167).

Ao inserir na discussão a questão das atividades não-agrícolas como essenciais para o desenvolvimento rural, chamando os agricultores (ou camponeses como advogamos!) de pluriativos, Graziano da Silva e Grossi (2000) descolam da representação estreita que confunde espaço rural com setor agrícola, predominante em tempos fordistas. Agora a representação passa a ser cada vez mais de camponeses pluriativos. Reafirmado, o que acabamos de explicitar, Graziano da Silva e Grossi (2000) ainda enfatizam:

No padrão fordista de organização do trabalho a atividade fora da unidade de produção era considerada como uma etapa do processo de proletarização. As transformações mais gerais da economia, particularmente a flexibilização do processo de trabalho industrial, facilitaram o crescimento da mão-de-obra pluriativa, que também interessa à indústria por ser mais econômica. A pluriatividade tornou-se permanente nas unidades familiares rurais, tendo em vista o novo ambiente social e econômico existente (GRAZIANO DA SILVA e GROSSI, 2000, p. 166) (grifos nossos).

\footnotetext{
${ }^{4} \mathrm{O}$ artigo de Graziano da Silva e Grossi foi publicado no ano 2000, o PRONAF passou a incorporar atividades não-agrícolas em meados do ano de 1999. Acreditamos, pois, que Graziano da Silva e Grossi estejam fazendo alusão a um período de transição ou anterior à incorporação das atividades não-agrícolas no PRONAF.
} 
Quando Graziano da Silva e Grossi (2000) falam que a mão de obra flexível era mais econômica, leia-se mais barata para o capitalista, com salários deprimidos e, portanto, mais precarizada. Na nossa compreensão, ao defenderem a pluriatividade nesses termos, Graziano da Silva e Grossi (2000) defendem que as políticas públicas deveriam então estimular a utilização de uma mão de obra mais barata, isto é, um trabalho mais precarizado para que assim as indústrias, ou melhor, o capitalismo, se beneficie.

Nesse ponto, se demarca mais um confronto entre as representações iniciais mobilizadas pelo PRONAF e estes dois teóricos acerca do camponês. Se no modelo fordista as representações hegemônicas compreendiam que um camponês que se utiliza de atividades não-agrícolas estava em vias de proletarização, agora isso muda. Ao produtivismo agrícola, rígido até certo ponto, se contrapõe as atividades não-agrícolas, flexíveis. As rendas nãoagrícolas, que eram vistas como algo negativo, agora passam a ser vistas como importantes para a criação de flexibilidades. Ao mesmo tempo em que refutam o modelo fordista, que neste momento ${ }^{5}$ ainda é hegemônico no PRONAF, Graziano da Silva e Grossi (2000) defendem a acumulação flexível e, assim, suas perversidades.

Toda essa defesa da pluriatividade ia então desembocar em políticas públicas que concebessem o rural para além da representação do produtivismo fordista. As representações hegemônicas mobilizadas no âmbito do fordismo, quase "endeusadoras" da cidade, tinham, até certo ponto, perdido força junto com a crise deste modelo e com os crescentes problemas urbanos. Não era mais necessário, nem recomendável, transformar espaço rural numa grande indústria produtivista subordinada à cidade. A "animalidade" do campo passava a ser vista com bons olhos pelas representações que emergiam e se tornavam hegemônicas. Antigas relações existentes no espaço rural, como a parceria, que outrora foram tratadas como atrasadas, passam a ser valorizadas. O assalariamento das indústrias poderia conviver com outras relações de trabalho. Enfim, se o urbano se encontrava com inúmeros problemas, a revalorização do espaço rural pelo capitalismo e pelo discurso do desenvolvimento se colocava como possibilidade.

Mas nesse "novo-velho" momento, como seria representado o espaço rural? Teria que se operar todo um movimento na tentativa de conceituar o rural de outra forma, distante

\footnotetext{
${ }^{5}$ Apesar de colocarmos o PRONAF, em seu início, como mais profundamente fordista, não esqueçamos que seu discurso guarda uma série de representações que nos parecem incoerentes com o paradigma fordista.
} 
da clara associação rural-agrícola que era posta pelas políticas públicas dominantes no período marcado pelo desenvolvimento fordista.

Dentro dessa perspectiva de desconstrução de representações e elaboração de outras representações sobre o rural, Graziano da Silva (1997), no Brasil, é uma referência importante. Junto com sua equipe, ele produziu sistematicamente um grande número de trabalhos sobre o que chama de "o novo rural brasileiro". Graziano da Silva (1997) tenta ao longo de seus trabalhos provar, a sua tese central de que:

\begin{abstract}
Na verdade, está cada vez mais difícil delimitar o que é rural e o que é urbano. Mas isso que aparentemente poderia ser um tema relevante, não o é: a diferença entre o rural e o urbano é cada vez menos importante. Pode-se dizer que o rural hoje só pode ser entendido como um "continuum" do urbano do ponto de vista espacial; e do ponto de vista da organização da atividade econômica, as cidades não podem mais ser identificadas apenas com a atividade industrial, nem os campos com a agricultura e a pecuária. (p. 43) ${ }^{6}$.
\end{abstract}

Perceba, pois, que como havíamos posto, Graziano da Silva procura descolar o conceito de rural da noção de agrícola, entretanto nessa nova representação, o rural ainda aparece como subordinado ao urbano, uma vez que é "continuun do urbano".

Contudo, a subordinação agora ocorre de maneira diferente daquela do período fordista. $\mathrm{Na}$ "antiga" representação, o espaço rural, identificado com a agricultura, tinha de se submeter ao urbano, identificado com a indústria. O espaço rural deveria, então, se tornar uma grande agroindústria. Agora, isso parece exagero e o rural não tem mais de se tornar uma grande indústria. Graziano da Silva (1997) esclarece:

\begin{abstract}
Mas isso é apenas suficiente para explicar parte das transformações do mundo rural contemporâneo, em particular aquelas que se coadunavam com o paradigma da industrialização da agricultura, que previam as "fábricas verdes" como protótipo da organização social do trabalho nos campos. Não há dúvida que poucas décadas atrás não se pensava que haveria um decréscimo gradual e persistente do emprego total dos setores industriais, à semelhança do que ocorria nas atividades agrícolas, nem que o emprego por conta própria e outras formas flexíveis de contratação típicas do mundo rural viessem a ser uma alternativa à estrutura fordista das fábricas modernas. (GRAZIANO DA SILVA, 1997, p. 43) (grifos nossos).
\end{abstract}

\footnotetext{
${ }^{6}$ Ao falar de "novo rural brasileiro", Graziano da Silva (2000) não está nos falando tão somente de um "novo" tipo de agricultor que aparece no "velho" rural brasileiro. Ele está produzindo toda uma nova representação do rural brasileiro. A palavra "novo" simboliza isto de maneira bastante forte, parece que tudo o que havia antes, toda desigualdade e todos os problemas ocorridos devido à Revolução Verde não mais existem.
} 
Haveria, portanto, uma forma de se revalorizar o rural, mesmo que subordinado. A urbanização do campo se daria por uma via diferente. A indústria não teria que transformar tudo à sua semelhança, teria apenas que integrar de maneira flexível as estruturas que resistiram à sua voracidade. O capitalismo tenta, pois, trazer tudo para si sem transformar em seu igual, até porque relações não-capitalistas podem ser utilizadas para a acumulação sem implicarem tantos custos quanto relações e estruturas tipicamente capitalistas implicariam.

Estas relações e estruturas não-tipicamente capitalistas podem ser importantes para os tempos flexíveis e constituir situações de subcontratação ou terceirização com a fábrica fordista, que não desapareceu. O que desapareceu foi a forma fábrica enquanto representação hegemônica.

Alguns teóricos se opõem à definição dada por Graziano da Silva ao rural, propondo outras interpretações (representações!). Entretanto, assim como Graziano da Silva, estes estudiosos não dão maior visibilidade às contradições no campo brasileiro. Carneiro (1998), por exemplo, destaca:

Torna-se cada vez mais difícil delimitar fronteiras claras entre as cidades e os pequenos vilarejos ou arraiais a partir de uma classificação sustentada em atividades econômicas ou mesmo em hábitos culturais. No entanto, tal processo não resulta, a nosso ver, numa homogeneização que reduziria a distinção entre o rural e o urbano a um continuum dominado pela cena urbana, como já foi formulado no tocante à realidade europeia (Lefebvre, 1972; Duby, 1984; Mendras, 1959; entre outros) e para a realidade brasileira (Graziano da Silva, 1996; Ianni, 1996, entre outros) (...) Ainda que os efeitos da expansão da "racionalidade urbana" sobre o campo, provocada pela generalização da lógica do processo de trabalho e da produção capitalista intensificados pelos mecanismos da globalização, não possam, de forma alguma, ser tratados com negligência, é precipitado concluir que tal processo resultaria na dissolução do agrário, e na tendência à transformação uniformizadora das condições de vida no campo (p.53).

Perceba, pois, que as ideias de Carneiro (1998) têm um caminho que aponta para uma dissociação entre o rural e agrícola, no entanto, a mesma contesta a posição de Graziano da Silva que aponta para uma urbanização no campo.

Abramovay (2000), com um trabalho de cunho mais economicista também converge de alguma forma para a posição de Carneiro (1998), quando destaca a repercussão que posições teóricas que sustentam a urbanização do rural teriam sobre as políticas de desenvolvimento. Em um trecho de sua obra, Abramovay (1992) afirma: 
Como definir o meio rural de maneira a levar em conta tanto a sua especificidade (isto é, sem encarar seu desenvolvimento como sinônimo de "urbanização"), como os fatores que determinam sua dinâmica (isto é, sua relação com as cidades)? Os impactos políticos da resposta a esta pergunta teórica e metodológica são óbvios: se o meio rural for apenas a expressão, sempre minguada, do que vai restando das concentrações urbanas, ele se credencia, no máximo, a receber políticas sociais que compensem sua inevitável decadência e pobreza. Se, ao contrário, as regiões rurais tiverem a capacidade de preencher funções necessárias a seus próprios habitantes e também às cidades - mas que estas próprias não podem produzir - então a noção de desenvolvimento poderá ser aplicada ao meio rural (p. 03)(grifos nossos).

$\mathrm{Na}$ nossa compreensão, todas as posições apresentadas se opõem a uma desvalorização do rural nos termos que teorias elaboradas no período fordista propunham. A revalorização daquilo que é chamado rural passa a ser uma constante nos trabalhos de alguns estudiosos que defendem o desenvolvimento rural. "Novo mundo rural" (cf. GRAZIANO da SILVA, 1997, 1999, 2000), "renascimento do rural" (cf. WANDERLEY, 2001) e outras expressões dão conta desse momento. Os recentes trabalhos de Veiga (2002, 2004a, 2004b) criticando os critérios do Instituto Brasileiro de Geografia e Estatística (IBGE) na definição do que e rural e do que é urbano no Brasil também são sintomas desse processo. Veiga (2002, 2004a) considera que o IBGE ao definir o rural pela negatividade, isto é, por aquilo que não é urbano, superestima este último em detrimento do rural. Este estudioso afirma que o Brasil é menos urbano e, portanto mais rural do que os números oficiais demonstram. Em seus trabalhos, Veiga (2002, 2004a, 2004b) se esforça por mostrar, a partir de gráficos e tabelas, que a migração campo-cidade decaiu nos últimos anos no Brasil. Enfim, há todo um esforço desses intelectuais em desconstruir uma representação do rural como desvalorizado e o negativo do urbano. Ao mesmo tempo, buscam de diferentes maneiras (inclusive confrontando-se muitas das vezes) fortalecer novas representações acerca do espaço rural. Vale sempre lembrar que a contradição não parece fazer parte das representações do rural que propõem.

Do exposto, podemos inferir que há entre esses intelectuais mais semelhanças do que diferenças. Todos eles apontam para a destruição de representações fordistas do rural e advogam um "novo rural", "um renascimento do rural", que se faz a partir da dissociação do rural e do agrícola. O que está posto de maneira diferente é a forma pela qual se dá a valorização do rural. A perspectiva de Graziano da Silva (1997, 1999), um tanto diferente das demais, trata da urbanização do campo como algo presente e procura refletir sobre a dissociação entre as noções de rural e agrícola. Dessa maneira, se Graziano da Silva rejeita a 
forma fábrica se expandindo por todos os lados, isso não quer dizer que o mesmo não pense em uma integração entre agricultura e indústria em padrões flexíveis.

Alguns poderiam, no entanto, considerar que Graziano da Silva pensa um fordismo em moldes europeus, uma "Revolução Verde dos camponeses". Entretanto, ao dissociar o rural do agrícola, Graziano da Silva aponta para uma compreensão que acaba por defender uma reinserção flexível dos camponeses e não em termos produtivistas típicos da Revolução Verde.

Todos estes intelectuais, na verdade, estão propondo compreensões que estão de acordo com as novas representações mobilizadas sob o novo modelo de desenvolvimento hegemônico, a acumulação flexível. A construção dessas representações não se deu em um "piscar de olhos" e estão inseridas nos processos que reestruturaram produtivamente o capitalismo, ajustando-o após a crise fordista. A destruição das representações que defendiam a rigidez era necessária para que daí se construíssem as representações que justificam as novas flexibilidades. Uma representação que revalorizasse o rural em sua especificidade se torna algo imprescindível, pois o rural sempre teve relações de trabalho menos rígidas que a cidade. O rural se torna, neste novo modelo de desenvolvimento, um verdadeiro "celeiro" de flexibilidades. Se as representações fordistas combatiam estas relações, mesmo que o capitalismo se reproduzisse a partir destas, agora elas são positivadas nas novas representações. Mas se evita dizer que essas relações não são apenas flexíveis, elas também são precárias.

Ao final dessa breve leitura sobre a revalorização do rural e as mudanças nas concepções sobre o mesmo, o leitor pode estar se perguntando sobre qual nexo haveria entre essa discussão e a política do PRONAF. Diríamos que foram discussões pautadas em argumentos como esses que influenciaram, em alguma medida, as mudanças observadas nas representações hegemônicas difundidas pelo discurso do PRONAF e também na prática ${ }^{7}$ do mesmo. Recordemos que no início desse tópico, foram apresentadas passagens em que Carneiro (1997) atacava as representações que embasavam o PRONAF ao mesmo tempo que Graziano da Silva e Grossi (2000) também faziam claras críticas ao modo como estavam fundamentadas as políticas de desenvolvimento rural no Brasil. No próximo sub-tópico, veremos como o governo federal responderá a essas críticas.

\footnotetext{
${ }^{7}$ Obviamente que essa discussão é bem mais extensa do que a que expomos nesta dissertação, aqui só a fizemos sucintamente.
} 


\section{Ajustando as representações utilizadas no discurso oficial}

No contexto brasileiro da década de 90, no qual emergiu uma série de conflitos no campo, debates como o que apresentamos sucintamente no tópico anterior expressavam a veiculação de discursos e representações que denotavam posicionamentos políticos. A partir desse contexto de crise, o governo brasileiro modifica o discurso oficial que organiza as representações, que por sua vez davam sustentação às políticas de desenvolvimento. $\mathrm{O}$ documento "Agricultura familiar, reforma agrária e desenvolvimento local para um novo mundo rural", publicado em 1999, serve de marco referencial para entender as redefinições das políticas de desenvolvimento rural. Dessa forma, o PRONAF enquanto política de desenvolvimento também tem suas representações alteradas.

Uma primeira pista da representação sobre o espaço rural que tal documento adota, é dada no seu título ao incorporar a expressão "novo rural ${ }^{8}$ ". Passemos a analisar que tipo de espaço rural o documento propõe.

O documento apresenta em seu início a seguinte proposição como central:

promover o desenvolvimento sócio-econômico sustentável, em nível local e regional, por meio da desconcentração da base produtiva e da dinamização da vida econômica, social, política e cultural dos espaços rurais - que compreendem pequenos e médios centros urbanos -, usando como vetores estratégicos o investimento na expansão e fortalecimento da agricultura familiar, na redistribuição dos ativos terra e educação e no estímulo a múltiplas atividades geradoras de renda no campo, não necessariamente agrícolas (MEPF/INCRA/SDR, 1999, p.01) (grifos nossos).

Esta proposição por sua vez se assenta em 6 premissas, sendo a primeira a seguinte: "O modelo de desenvolvimento focado na industrialização concentrada em áreas metropolitanas e na agricultura patronal encontra-se em crise"(MEPF/INCRA/SDR, 1999, p. 01).

Há, portanto, claras mudanças entre o primeiro conjunto de políticas públicas da qual o PRONAF faz parte, que o fordismo era hegemônico, e o segundo, no qual já consta na proposição central o fortalecimento da agricultura familiar a partir de atividades que não são agrícolas. Além de apontar uma proposta um tanto quanto diferente do PRONAF, muito mais relacionada a um modelo de desenvolvimento de acumulação flexível, o documento não deixa

\footnotetext{
${ }^{8}$ Ao que nos consta, Graziano da Silva foi o primeiro estudioso brasileiro a falar em "novo rural" nesses termos e já expressava ideias como as que acabamos de expor desde meados da década de 1990.
} 
de fazer críticas ao modelo fordista. Este é um movimento necessário, destruir as antigas representações hegemônicas para que as novas emirjam.

A revalorização do espaço rural, tida como condição básica para a inserção do rural no modelo capitalista de desenvolvimento da acumulação flexível, comparece explicitamente no documento no trecho que diz: "a proposta defende a revalorização do mundo rural firmando-se numa nova concepção do desenvolvimento socioeconômico, formulada mais num quadro territorial do que setorial”. (MEPF/INCRA/SDR, 1999, p. 02).

Se no primeiro enfoque, o programa relacionava de maneira não explícita o rural ao setor agrícola, pautando-se assim em uma representação produtivista e setorial, disseminada fortemente no âmbito do fordismo; o documento lançado posteriormente passa a adotar uma perspectiva que procura compreender o rural não como um setor, mas como um espaço, um território no qual se circunscrevem múltiplos setores de atividade. É a partir desse entendimento que o PRONAF passará a financiar atividades que não fazem parte do setor agrícola.

O espaço rural passa a ser identificado a partir de 4 funções, são elas:

A de espaço produtivo, dominantemente agrícola e agro-industrial, mas com crescentes opções de múltiplas atividades;

A de espaço de residência, tanto para os agricultores como para trabalhadores urbanos que optam por um padrão de moradia diferenciado no cotidiano ou nos finsde-semana;

A de espaço de serviços, inclusive os de lazer, turismo, etc.;

A de espaço patrimonial, como base de estabilidade das condições de subsistência, valorizado pela preservação dos recursos naturais e culturais (MEPF/INCRA/SDR, 1999, p. 02) (grifos nossos).

Perceba, pois, como estas funcionalidades do espaço rural se relacionam com as ideias de estudiosos como Kageyama (2004) que advogam um modelo de desenvolvimento que retire o agrícola do centro.

A discussão sobre a definição de rural é praticamente inesgotável, mas parece haver um certo consenso sobre os seguintes pontos: a) rural não é sinônimo de e nem tem exclusividade sobre o agrícola; b) o rural é multissetorial (pluriatividade) e multifuncional (funções produtiva, ambiental, ecológica, social); c) as áreas rurais têm densidade populacional relativamente baixa (o que pode mesmo constituir sua própria definição legal); d) não há um isolamento absoluto entre os espaços rurais e as áreas urbanas (KAGEYAMA, 2004, p. 02). 
Problematizemos sucintamente estas novas funções do espaço rural que o documento indica. Primeiramente, o documento relaciona o espaço rural com a produtividade agrícola e o agroindustrial, mas tem logo o cuidado de dizer que outras múltiplas atividades são crescentes no campo. Sobre esse aspecto, talvez já tenhamos falado muito. Abordamos como essa nova representação do rural tem a ver com o modelo de desenvolvimento flexível em contraposição ao modelo de desenvolvimento fordista. Vamos ao segundo ponto: espaço rural como "espaço de residência". O documento logo ressalta o espaço rural enquanto a moradia dos trabalhadores rurais, mas se atem ao "espaço de residência" para trabalhadores urbanos no dia-a-dia ou nos fins de semana. Aqui se ressalta uma representação do espaço rural bastante em voga, em contraposição ao urbano caótico com todos os seus males, o espaço rural é revalorizado como um espaço mais próximo da natureza, não caótico, quase paradisíaco, um espaço de fuga, para onde fluem aqueles que tentam escapar da massacrante vida da cidade. Os neorrurais (cf. GIULIANNI, 1990) seriam os melhores representantes dos novos tempos, mas não os únicos. Indivíduos das classes médias urbanas, muitas vezes com formação acadêmica se estabelecem cada vez mais no espaço rural. Não são camponeses, embora alguns trabalhem com agricultura orgânica, permacultura e outras formas alternativas de agricultura. Muito embora se estabeleçam no campo, seus hábitos são muito mais urbanos do que rurais. De alguma maneira, o terceiro (espaço de serviços, inclusive de lazer, turismo) e o quarto ponto (espaço patrimonial, como base de estabilidade das condições de subsistência, valorizado pela preservação dos recursos naturais e culturais) também se valem de representações nos termos que expomos. Embora sejam representações do rural revalorizado, não seriam estas representações, representações urbanas acerca do rural?

Por mais que estes sujeitos já estejam inseridos, de algum modo, no espaço rural brasileiro, a sua presença ainda é bastante tímida e contraditória. Se muitas destas representações nascem em contraposição ao capitalismo em seu momento fordista, elas não escapam de ser utilizadas pelo próprio capitalismo. O novo modelo de desenvolvimento consegue muito bem alocá-las no seu discurso. O espaço rural quase que naturalizado, a calma da vida rural e formas alternativas de agricultura são utilizadas pelo capitalismo enquanto representações utilizadas numa perspectiva de consumo do espaço, colonizando até mesmo o próprio lazer. O turismo rural não seria isso? O turismo rural não seria um negócio? No turismo rural não se utiliza trabalho precarizado também? Muitos produtos orgânicos não 
são simples mercadorias nas prateleiras das grandes redes de supermercado? O discurso do PRONAF, apresenta, pois, uma proposta que não pensa o contraditório, mas ao contrário, é uma estratégia para subsumir as contradições subjacentes ao processo de produção do espaço rural.

Analisadas, mesmo que de maneira rápida, as representações que sustentam as "novas" funções do espaço rural, passemos agora a outras mudanças nas representações que dão sustentação às políticas de desenvolvimento rural. Dentre essas mudanças, uma que começa ainda a se insinuar nas representações hegemônicas que sustentam o PRONAF diz respeito ao territorial enquanto nível de gestão ${ }^{9}$. Nesse sentido, o seguinte trecho é explícito “(...) o rural não se confunde com o agrícola e a perspectiva setorial deve ser substituída pela perspectiva territorial, tendo como elemento central as potencialidades específicas de cada local, valorizadas pela dinâmica da globalização" (MEPF/INCRA/SDR, 1999, p. 02) (grifos nossos).

O documento, apesar de ainda fazer maiores referências ao "desenvolvimento local", inclusive no seu título, já utiliza o termo territorial enquanto forma de potencializar recursos dos lugares.

Montenegro Gómez (2006), estudando os vários discursos sobre o desenvolvimento, ao analisar as diferenças entre os discursos sobre desenvolvimento local e sobre o territorial, afirma que "não resulta fácil estabelecer uma fronteira entre um e outro, todavia, há um certo espaço comum onde ambos compartilham de um bom número de premissas, objetivos e instrumentos para pensar o desenvolvimento no meio rural" (p. 196).

Tendo mais semelhanças do que diferenças, as duas representações quando materializadas resultam em práticas similares. Parece ser muito mais uma mudança nos termos do que na prática, já que os dois fazem referência a um desenvolvimento autocentrado, endógeno, de baixo para cima.

O PRONAF já era desde o seu início um programa assentado em bases de desenvolvimento endógeno, a constituição de conselhos para a sua gestão é prova disso. Essa forma de controle sobre a gestão da política pública e, portanto, do espaço rural, já estava

\footnotetext{
${ }^{9}$ A incorporação do termo "territorial" não se contrapõe apenas ao "setorial", mas se contrapõe também a formas de controle centralizadas no Estado, como as que ocorreram com a Revolução Verde.
} 
posta desde o primeiro PRONAF, sendo muito mais perceptível na linha do PRONAF Infraestrutura, que não é objeto da nossa pesquisa.

Somente no ano de 2003, início do mandato de Luís Inácio Lula da Silva, a proposta de gestão a partir dos "Territórios" tomará maior "corpo". Essa transformação no PRONAF começa com a transferência do PRONAF-Infraestrutura para a recém-criada Secretaria do Desenvolvimento Territorial (SDT), sob a responsabilidade do MDA. Nesse período a gestão do programa foi retirada dos Conselhos Municipais. Agora a gestão do desenvolvimento territorial passa para os "Territórios". De acordo com Schneider et al. (2004), a SDT compreendia que o município era uma unidade pouco adequada à gestão das relações necessárias ao desenvolvimento rural, desta forma criou os Territórios, agrupamentos de municípios, como unidade gestora para que o programa pudesse ampliar o seu raio de ação ${ }^{10}$. Existe, no entanto, uma mudança considerável quanto ao enfoque de desenvolvimento endógeno adotado no Governo FHC e no Governo Lula. Enquanto no primeiro o PRONAF Infraestrutura e Serviços Municipais visava sobretudo o provimento de infraestrutra, no segundo o enfoque passa a compreender o fortalecimento das organizações representativas dos agricultores familiares, passando a incentivar a participação dos mesmos.

Na acepção governamental do Governo Lula, o Território é

Um espaço físico, geograficamente definido, geralmente contínuo, caracterizado por critérios multidimensionais que se relaciona interna e externamente por meio de processos específicos, onde se pode distinguir um ou mais elementos que indicam identidade e coesão social, cultural e territorial (MDA/SDT/CONDRAF, 2003).

Dois elementos são, pois, centrais para se entender o território da proposta governamental: coesão e identidade. Esquece-se que territórios também são produtos de conflitos. Tudo parece convergir aprioristicamente para uma coesão, um consenso. Não há qualquer menção a respeito dos conflitos.

Mais uma vez, os problemas do "velho-contemporâneo" rural são esquecidos. Simplesmente não existem. Essa acepção do território é coerente com a perspectiva de desenvolvimento endógeno que os novos paradigmas do desenvolvimento buscam trazer à

\footnotetext{
${ }^{10}$ Schneider et al. (2004) afirma no entanto que desde 2001 havia um movimento que prezava por iniciativas intermunicipais. "A partir de novembro de 2001, começa a se esboçar uma reformulação no Programa no sentido de promover ações que não se limitem à esfera municipal. A Resolução $n^{\circ} 27$ trouxe como novidade a previsão da utilização de 5 a $10 \%$ do valor da cota de cada estado para apoio a projetos de desenvolvimento rural e fortalecimento da agricultura familiar apresentados por organizações intermunicipais e a exclusão do programa dos municípios com mais de 100 mil habitantes. Previu-se, porém, uma regra de exceção para os municípios com população acima desse patamar desde que integrados em ações intermunicipais e que os demais municípios parceiros tivessem menos de 100 mil habitantes.
} 
tona, focando na identidade, na coesão, no consenso. Em nenhum paradigma de desenvolvimento territorial o conflito está suposto.

\section{Novas linhas do PRONAF: ações que mobilizam representações disseminadas no pós- fordismo}

Existe um movimento nas representações hegemônicas do PRONAF, há cada vez mais a tentativa de minar representações veiculadas sob a hegemonia do modelo de desenvolvimento fordista para que se abra espaço para representações da era pós-fordista, não necessariamente flexíveis ${ }^{11}$. Além de tentar "corrigir" as diretrizes do PRONAF, a mudança ainda se insinua no tocante a acrescentar linhas ao programa que mobilizavam representações difundidas no contexto de acumulação flexível.

Em 1999, o programa já havia iniciado ações nesse sentido, quando passou a financiar atividades não-agrícolas, o que já dista da representação do espaço rural enquanto puramente agrícola. Outra mudança que também aponta nessa direção se faz em 2003, início do Governo Lula, quando são criadas algumas novas modalidades do PRONAF que demarcam transformações importantes nesta política pública, evidenciando a efetivação de ações que veiculam um conjunto de representações pós-fordistas.

Dentre as novas modalidades de crédito, surge com a resolução 3001 do Banco Central o "PRONAF Florestal", linha de crédito de investimentos para sistemas agroflorestais. Em 2003, criam-se as modalidades "PRONAF Agroecologia" e "PRONAF Semiárido", a primeira com o intuito de apoiar a produção agropecuária que não se utiliza de quimificação e a segunda com o intuito de financiar projetos que prezem pela convivência com o semiárido. É criada também a modalidade "PRONAF Eco" que visa o financiamento de projetos de investimento em tecnologias de energia renovável e ambientais, silvicultura, armazenamento hídrico, pequenos aproveitamentos hidroenergéticos e adoção de práticas conservacionistas e de correção da acidez e fertilidade do solo.

Dessa maneira, se durante o período industrial, a representação da natureza que imperava era a de algo a ser dominado, em dicotomia com o homem, agora as novas linhas do

\footnotetext{
${ }^{11}$ Muitas dessas representações foram criadas em resposta ao capitalismo. Muitas dessas representações também são utilizadas pela esquerda, de maneira diferente das expostas no PRONAF. Tais representações não foram criadas para dar sustentação ao capitalismo, mas no movimento que resultou em um novo ajuste capitalista, muitas passaram a ser manipuladaspelo capitalismo para seus interesses.
} 
PRONAF materializam uma perspectiva mais sensível a questões de sustentabilidade, com investimentos em formas alternativas de agricultura, como as agroflorestas e a agroecologia. O "PRONAF Semiárido" também caminha nesse sentido, se as antigas políticas da década de 1970, advogavam hegemonicamente o combate à seca, agora o "PRONAF Semiárido" se utiliza de uma concepção de convivência com a seca, de relação com a natureza que não se exprima pela dominação da mesma.

Desse modo, o que aparecia de maneira incipiente nos primeiros discursos do PRONAF, aqui toma maior consistência ao serem criadas linhas específicas do programa que contemplem a perspectiva do desenvolvimento sustentável.

A representação do rural dissociado do agrícola também está presente nessas novas linhas. Se em 1999, o PRONAF deixa de financiar apenas atividades agrícolas, em 2003 será criada uma linha especial, o "PRONAF Turismo Rural” que como o próprio nome diz financia atividades ligadas ao turismo rural.

Além destes, também foram criados o "PRONAF Mulher" e o "PRONAF Jovem Rural" no ano de 2004. Nesse contexto, surgem ainda outras linhas como o "PRONAF Pesca" e "PRONAF Máquinas e Equipamentos", além do "PRONAF Mais Alimentos".

Observemos, pois, como o documento "Agricultura familiar, reforma agrária e desenvolvimento local para um novo mundo rural" antecipa mudanças no discurso hegemônico antes mesmo de se criarem as novas modalidades. O espaço produtivo, o espaço de serviços e o espaço patrimonial enquanto diferentes funções do espaço rural encontram-se contemplados nas novas linhas do PRONAF.

\section{CONSIDERAÇÕES FINAIS}

Do exposto, podemos entender que por todos os lados, eram evidenciados os limites do fordismo e da Revolução Verde levada à cabo no Brasil. No espaço rural, nunca dissociado do urbano, os camponeses lutavam contra a expropriação e aqueles que haviam sido expropriados lutavam bem mais que por um pedaço de terra, lutavam por todo um modo de vida. Diversos movimentos sociais surgem no campo brasileiro. Concomitantemente, no campo, a flexibilização emerge, se contrapondo ao fordismo. O campesinato e suas 
"ineficiências", características do seu modo de vida, agora passam a ser "incorporadas" à flexibilização. As representações que não reconheciam o lugar do campesinato na contemporaneidade passam a ser substituídas por representações que realçam qualidades específicas deste sujeito social. Resumindo, o campesinato é descoberto como um potencial "cliente" do desenvolvimento. Entretanto, só incorporar o camponês do modo como ele é não parece interessante para o capitalismo, faz-se necessária uma série de ajustes.

O PRONAF, uma política de desenvolvimento, surge nesse contexto marcado por mudanças nas representações de desenvolvimento a partir das mudanças no próprio modelo de desenvolvimento, daí a incoporação do campesinato. O PRONAF, que em um primeiro momento parecia muito mais um programa fundado em um modelo de desenvolvimento rural fordista, passa cada vez mais a incorporar representações disseminadas no contexto da acumulação flexível.

O PRONAF concebe um rural que passa a ser identificado pelo territorial e não pelo setorial, demarcando distâncias em relação ao fordismo, que associava de maneira estrita o rural ao setor agrícola. Nas "novas" representações que evidenciam uma perspectiva espacial, o rural passa a ser concebido como um espaço que abriga diversas atividades, sejam elas agrícolas, industriais ou pertencentes ao setor de serviços.

Entretanto, nenhuma dessas representações, características dos tempos flexíveis, enfrenta os fundamentos do conflito agrário como a concentração de terras e de riquezas nas mãos de poucos. Sem conceber suas relações com a totalidade, as ações previstas pelo PRONAF se tornam demasiadamente limitadas.

As representações hegemônicas disseminadas pelo desenvolvimento sempre se pautaram em uma posição que ignora os conflitos latentes no campo. O desenvolvimento sempre tentou mudar para não mudar, desenvolver para não resolver. Dessa forma, no espaço rural do desenvolvimento há pobreza, mas não há conflito. Pobreza que, de acordo com o discurso do desenvolvimento, pode ser aliviada por um conjunto de intervenções, de políticas públicas que melhorarão a vida de todos ao convergirem para os modelos de desenvolvimento hegemônicos.

O governo federal, ao utilizar as representações hegemônicas do desenvolvimento faz uma clara opção por não reconhecer os conflitos em suas políticas públicas. 


\section{REFERÊNCIAS}

ABRAMOVAY, R. Paradigmas do Capitalismo Agrário em Questão. 2. ed. São PauloCampinas: Hucitec/Edunicamp, 1992.

Funções e medidas da ruralidade no desenvolvimento contemporâneo. Rio de Janeiro: IPEA, 2000. (Texto para Discussão, nº 702).

ALBANO, G. P. Globalização da agricultura e concentração fundiária no município de Ipanguaçu - RN. Dissertação de Mestrado em Geografia - Universidade Federal do Rio Grande do Norte. Natal: 2005.

ANTUNES, R. Adeus ao trabalho? Ensaios sobre a metamorfose e a centralidade do mundo do trabalho. São Paulo: Cortez, 2003.

BITTENCOURT, G. A. Abrindo a caixa-preta: o financiamento da agricultura familiar no Brasil. Dissertação de Mestrado em Geografia - Universidade Estadual de Campinas: Campinas, 2003.

CARNEIRO, M. J. Política Pública e Agricultura Familiar: uma leitura do PRONAF. In: Estudos Sociedade e Agricultura, v. 8, p. 70-85, Rio de Janeiro: UFRJ, 1997.

. Ruralidade: novas identidades em construção. In. Estudos Sociedade e Agricultura v. 11, p. 53-75, Rio de Janeiro: UFRJ, 1998.

ELIAS, D. Globalização, fragmentação e reorganização do espaço agrário cearense. In: GEONORDESTE, Vol. 01, $\mathrm{n}^{\circ}$ 02. Aracaju: UFS, 2000.

ESCOBAR, A. Planejamento. In: SACHS, W. Dicionário do Desenvolvimento. Petrópolis: Vozes, 2000.

ESTEVA, G. Desenvolvimento. In: SACHS, W. Dicionário do Desenvolvimento. Petrópolis: Vozes, 2000.

GIULIANI, G. M. Neorruralismo: O Novo Estilo dos Velhos Modelos. In: Revista Brasileira de Ciências Sociais, v. 14, 1990.

GRAMSCI, A. Americanismo e Fordismo. In: Cadernos do Cárcere. Vol, IV. Rio de Janeiro: Civilização brasileira, 2001.

GRAZIANO DA SILVA, J. F. A modernização dolorosa: estrutura agrária, fronteira agrícola e trabalhadores rurais no Brasil. Rio de Janeiro: Zahar Editores, 1982. 
UNICAMP, 1996

.A nova dinâmica da agricultura brasileira. Campinas:

1997.

O novo rural. In: Nova economia 7(1):43-81. Belo Horizonte:

de Economia da Unicamp, 1999.

O novo rural brasileiro. 2. ed. Campinas: Editora do Instituto

e GROSSI, M. E. O novo rural brasileiro. In: José Graziano da Silva. (Org.). Ocupações rurais não-agrícolas: Oficina de atualização temática, , v. 1, p. 25 39. Londrina: IAPAR, 2000.

KAGEYAMA, A. Desenvolvimento rural: conceito e um exemplo de medida. In: XLII Congresso da Sociedade Brasileira de Economia e Sociologia Rural. Cuiabá: 2004.

LEFEVBRE, H. A revolução urbana. Belo Horizonte: UFMG, 1999.

La presencia y la ausencia: contribuición a la teoría de las representaciones.

Tradução de Oscar Barahona y Uxoa Doyhamboure. México: Fondo de Cultura Economica, 2006.

LIPIETZ. A. Miragens e milagres: problemas da industrialização no Terceiro Mundo. Tradução de Catherine Marie Mathieu. São Paulo: Nobel, 1988.

MARAFON, G. J. Industrialização da Agricultura e Formação do Complexo Agroindustrial no Brasil. Nº3, Rio de Janeiro: Geo UERJ, 1998, p.7-21.

MDA/SDT/CONDRAF. Referências para um programa territorial de desenvolvimento rural sustentável. Brasília, CONDRAF/NEAD, Texto para Discussão nº 04, 2003.

MEPF/INCRA/SDR. Agricultura familiar, reforma agrária e desenvolvimento local para um novo mundo rural - Política de desenvolvimento rural com base na expansão da agricultura familiar e sua inserção no mercado. Brasília: 1999.

MONTENEGRO GOMEZ, J. Desenvolvimento em (des)construção: narrativas escalares sobre desenvolvimento territorial rural. Tese de Doutorado (Geografia)- Universidade Estadual Paulista, Presidente Prudente: 2006.

OLIVEIRA, A. U. A Geografia Agrária e as transformações territoriais recentes no campo brasileiro. In: CARLOS, A. F. A. (Org.). Novos caminhos da geografia. São Paulo: Contexto, 1999.

PRONAF. Lei no 1946 de 28 de junho de 1996 (cria o Programa Nacional de Fortalecimento da Agricultura Familiar - PRONAF e dá outras providências). Brasília: 1996. 
SACHS, W. Introdução. In: SACHS, W. Dicionário do Desenvolvimento. Petrópolis: Vozes, 2000.

SANTOS, M. Economia Espacial. São Paulo; Hucitec, 1979.

SCHNEIDER, S. et al. Histórico, Caracterização e Dinâmica Recente do PRONAF. In. SCHNEIDER, S. et al.(Org.). Políticas Públicas e Participação Social no Brasil Rural. Porto Alegre, 2004.

SORJ, B. Estado e Classes Sociais na Agricultura Brasileira. 2. ed. Rio de Janeiro: Zahar, 1980.

VEIGA, J. E. O Brasil rural precisa de uma estratégia de desenvolvimento. Brasília: NEAD, 2001. . Cidades Imaginárias. Campinas: Autores Associados, 2002.

. Nem tudo é urbano. In. Ciência e Cultura, São Paulo: SBPC, 2004a.

. A dimensão rural do Brasil. Estudos Sociedade e Agricultura (UFRJ), Rio de Janeiro, n.22. 2004b

VILELA, S. L. O. Qual Política para o Campo Brasileiro? (do Banco Mundial ao Pronaf: a trajetória de um novo modelo). In: Congresso Brasileiro de Economia e Sociologia Rural. Natal: Sober, 1997

- A emergência de uma nova ruralidade nas sociedades modernas avançadas: Estudos Sociedade e Agricultura, v. 15, p. 69-129. Rio de Janeiro: UFRJ, 2001.

WILKINSON, J. O Estado, a agricultura e a pequena produção. Rio de Janeiro: 2008.

\section{Autor}

Michell Leonard Duarte de Lima Tolentino - Possui Graduação em Geografia pela Universidade Federal da Paraíba (UFPB) e Mestrado em Geografia pela Universidade de São Paulo (USP). Atualmente é Professor do Instituto Federal do Tocantins (IFTO), Campus Dianópolis.

Artigo recebido em: 25 de novembro de 2016.

Artigo aceito em: 16 de dezembro de 2016. 